\title{
Growth, yield and bulb quality as influenced by sources and levels of sulphur in onion (Allium cepa L.) under calcareous soil of North Bihar
}

Anamika Kumari, Bindhyachal Ram, Udit Kumar and S. S. Prasad

MEMBERS OF RESEARCH FORUM:
Corresponding author :
Anamika Kumari, Krishi Vigyan
Kendra (B.A.U.), Darisai, East
Singhbhum (Jharkhand) India
Email: anamikakumari1970@gmail.
com
com

Co-authors :

Bindhyachal Ram, Krishi Vigyan

Kendra (B.A.U.), Garhwa

(Jharkhand) India

Udit Kumar and S.S. Prasad, Tirhut College of Agriculture, Dr. Rajendra Prasad Central Agriculture University, Pusa (Bihar) India
Received : 07.09.2018; Revised : 09.11.2018; Accepted : 19.11.2018

\section{Summary}

An experiment was conducted at Tirhut College of Agriculture, RPCAU, Dholi, Muzaffarpur, Bihar during Rabi, 2010-11 to study the effect of sources and levels of sulphur on growth, yield and bulb quality in onion. The treatment consists of two sources of sulphur and four levels of sulphur by adopting Factorial RBD with three replications. The results on vegetative growth (plant height, number of leaves plant ${ }^{-1}$ and neck thickness), yield attributing parameters (bulb weight, equatorial and polar diameter), total bulb yield, physiological losses of weight (PLW) and total soluble solid (TSS) revealed significant variations among the levels of sulphur in onion. However, no significant variations were recorded between the sources of sulphur in onion, except bulb weight. Gypsum recorded higher plant height, neck thickness, average bulb weight, polar diameter, total bulb yield and TSS than elemental sulphur. Gypsum as a source of sulphur also reduces the production of doubles and bolter along with better shelflife of onion by reducing PLW, rotting and sprouting. Among the levels of sulphur, irrespective of sources, sulphur @ $30 \mathrm{~kg} \mathrm{ha}^{-1}$ recorded significantly higher plant height $(59.89 \mathrm{~cm})$, number of leaves plant ${ }^{-1}(15.66)$, polar diameter $(5.41 \mathrm{~cm})$, equatorial diameter $(5.21 \mathrm{~cm})$, average bulb weight $(66.00 \mathrm{~g})$, total bulb yield $\left(241.33 \mathrm{q} \mathrm{ha}^{-1}\right)$ and TSS $(12.54 \%)$ than other levels. However, statistically parity was observed with application of sulphur @ 15 and $30 \mathrm{~kg} \mathrm{ha}^{-1}$ for above mentioned parameters. Application of sulphur @ $30 \mathrm{~kg} \mathrm{ha}^{-1}$ in form of gypsum may be recommended in onion crop for obtaining higher bulb yield having better keeping quality.

Key words : Onion, Gypsum, Elemental sulphur, Growth, Yield, Quality

How to cite this article : Kumari, Anamika, Ram, Bindhyachal, Kumar, Udit and Prasad, S.S. (2018). Growth, yield and bulb quality as influenced by sources and levels of sulphur in onion (Allium cepa L.) under calcareous soil of North Bihar. Asian J. Soil Sci., 13 (2) : 126-130 : DOI : 10.15740/HAS/AJSS/ 13.2/126-130. 